\title{
Lower Serum L-Tryptophan Availability in Depression as a Marker of a More Generalized Disorder in Protein Metabolism
}

Michael Maes, M.D., Ph.D. Annick Wauters, M.Sc., Robert Verkerk, R.T., Ing., Paul Demedts, M.Sc., Hugo Neels, Ph.D., Ann Van Gastel, M.D., Paul Cosyns, M.D., Simon Scharpé, Ph.D., and Roger Desnyder, M.D.

Recently, it has becn reported that major and melancholic depression are accompanied by a lower availability of total L-tryptophan ( $L-T R P)$ to the brain and by significant changes in electrophoretically separated protein fractions, such as albumin and $\alpha_{2}$-globulin. The aim of this study was to examine the relationships between serum L-TRP availability and total serum protein, albumin, and $\alpha_{2}$-globulin in 42 depressed and 24 normal subjects. In depressed and normal subjects, alone and together, there were significant and positioe correlations betaeen serum L-TRP and total serum protein or albumin concentrations. In the depressed subjects, but not in normal controls, there were significant inverse relationships between the L-TRP/ competing amino acid ratio and the $\alpha_{2}$-globulin fraction.

KEY WORDS: Acute phase proteins; Electrophoresis;

Serotonin; L-tryptoplan; Albumin

There is now evidence that major depression is accompanied by disorders in the peripheral and central me-

From the Clinical Research Center (MM, RD), Mental Health, University Department of I'svchiatry, $A Z$ Stuivenberg. Antwerp; Department of P'sychiatry (MM, $A V(B, P C)$, Liniversity Hospital of Antwerp; Laboratory of Clinical Chemistry (AW, PD, HN), AZ Middelheim, Antwerp; Department of Medical Biochemistry (RV, SS), University of Antwerp, Edegem, Belgium.

Address correspondence to: Michael Maes, M.D., Ph.D., Director Clinical Research Center Mental Health, Lniversity Department of Psychiatry, AZ. Stuivenberg, 267 Lange Beeldekensstraat, 2060) Antwerp, Belgrium.

Received February 6, 1995; revised Iugust 31, 1995; accepted September 21,1995 .
Serum L-TRP and albumin were significantly lower in melancholic subjects than in normal and minor depressed subjects. Depressed subjects had a significantly lower L-TRP/competing amino acid ratio and significantly higher serum $\alpha_{2}$-globulin than normal controls. Total serum protein was significantly lower in major depressed subjects than in normal controls. The results suggest that lower L-TRP availability to the brain in depression is related to lower serum albumin and to increased $\alpha_{2}$-globulin fraction, which are both hallmarks of the acute phase response in depression. The results further corroborate the hypothesis that lowered L-TRP availability in depression is related to the acute phase response in that illness.

[Neuropsychopharmacology 15:243-251, 1996]

tabolism of serotonin (5-HT) and by an acute phase response. One on the most consistently reported abnormal findings in serotonergic metabolism in major depression is a reduced availability of L-tryptophan (L-TRP) to the brain (DeMyer et al. 1981; Maes et al. 1990a; Cowen et al. 1989). Thus, serum L-TRP as well as the ratio of L-TRP to the sum of amino acids known to compete for the same cerebral uptake mechanisms (competing amino acids, e.g., tyrosine, valine, leucine, isoleucine, phenylalanine) is lower in major depressed subjects than in normal controls (review: Maes and Meltzer 1995). The relevance of these findings for the pathophysiology of major depression is underscored by recent reports that in normal and depressed subjects, acute lowering of plasma L-TRP may cause an acute lowering of mood or rapid clinically significant return of depressive symp- 
toms, respectively (Young et al. 1985; Delgado et al. 1990; Heninger et al. 1992).

There are now several reports that major depression is accompanied by an acute phase response, as demonstrated by higher plasma levels of positive acute phase proteins, such as haptoglobin, $\alpha_{1}$-antitrypsin, and ceruloplasmin, increased concentrations of the electrophoretically separated serum $\alpha_{2}$-globulin fraction, and lower concentrations of negative acute phase proteins, such as albumin and transferrin (Maes et al. 1991, 1992a,b, 1993, 1994a; Joyce et al. 1992; Song et al. 1994; Sluzewska et al. 1995b). Moreover, an acute phase response has also been observed in the olfactory bulbectomized rat model of depression (Arnold and Meyerson 1990; Song and Leonard 1994). We have argued that the acute phase response in major depression is related to an increased production of interleukin-6 (IL-6) in major depression (Maes et al. 1993; Sluzewska et al. 1995a,b). Indeed, IL-6 is a pleiotropic cytokine, which is mainly produced by activated cells of the monocyte/macrophage lineage and is a major mediator of the acute phase response in humans (Mackiewicz et al. 1988; Hirano 1991). This hypothesis is underscored by the significant relationships between IL- 6 secretion and acute phase proteins, such as haptoglobin and C-reactive (positive) and transferrin (negative) (Maes et al. 1993; Sluzewska et al. 1995b).

Recently, it has been hypothesized that the reduced L-TRP availability to the brain in depression may be related to the acute phase response in that illness (Maes et al. 1993, 1994b). Indeed, highly significant relationships were found between plasma L-TRP availability and plasma haptoglobin (negative), transferrin (positive), and IL-6 production by peripheral blood mononuclear cells (negative) (Maes et al. 1993). Some factors that may explain the reduced L-TRP availability during an acute phase response are (1) peripheral amino acids are used for leukocyte activity and synthesis of acute phase proteins (Blackburn et al. 1979; Moldawer et al. 1987; Hasselgren et al. 1988; Heinrich et al. 1990; Wolvekamp and Marquet 199(0), and (2) indoleamine 2,3 dioxygenase (IDO), a major L-TRP catabolizing enzyme, may be induced during the acute phase response (Takikawa et al. 1984, Brown et al. 1989; Moroni et al. 1991). The latter hypothesis is underscored by the significant inverse relationship between lower plasma L-TRP and increased neopterin concentrations in major depression (Maes et al. 1994b). Indeed, it is known that IDO and GTP hydroxylase, which stimulates the synthesis of neopterin in activated monocytes/macrophages, are induced simultaneously during an acute phase response (Fuchs et al. 1990), 1991).

Another possible explanation for the inverse relationship between lower L-TRP availability and indices of the acute phase response in depression revolves around the binding of L-TRP to albumin, which is an acute phase reactant. Linder normal conditions, L-TRP circu- lates in the blood with a minor fraction free, whereas $70 \%$ to $90 \%$ of L-TRP is loosely bound to serum albumin (Rao 1987; Curzon and Sarna 1984; Fernstrom 1984; Yuwiler et al. 1977; McMenamy and Oncley 1958). This explains that the availability of circulating L-TRP is generally influenced by its binding to albumin (Curzon and Knott 1975). Moreover, the extraction of plasma L-TRP by the brain is, in part, related to competition of the brain transport site with plasma albumin, that is, it is proposed that the blood-brain barrier (BBB) transport site of L-TRP and its competing amino acids strips off albumin as it passes through the brain capillaries (Pardridge 1979; Smith et al. 1990). Therefore, the influx of L-TRP into the brain depends on plasma concentrations of all L-TRP, that is, free and/or total L-TRP, as well as on the concentrations of albumin and the competing amino acids (Pardridge 1979; Yuwiler et al. 1977). Thus, reduced serum albumin concentrations in major depression (Maes et al. 1991; Song et al. 1994), could be accompanied by lower total L-TRP concentrations and, consequently, by a lowered extraction of L-TRP by the brain.

The aim of the present study was to examine the relationships between plasma availability of L-TRP to the brain and the serum concentrations of albumin, total serum protein, and the $\alpha_{2}$-globulin fraction. A positive correlation between L-TRP availability and serum albumin or total serum protein and a negative correlation between L-TRP availability and the elecrophoretically separated $\alpha_{2}$-globulin fraction would be expected, if the hypothesis that lowered L-TRP availability is related to the acute phase response is correct.

\section{SUBJECTS}

In this study, 66 subjects participated, 24 healthy controls and 42 depressed inpatients, and were admitted to the psychiatric ward of the University Hospital of Antwerp between October 1992 and April 1994. The depressed patients were categorized according to DSMIII-R criteria (APA 1987) using the Structured Clinical Interview for DSM-III-R, version 1989 (SCID) (Spitzer et al. 1990) into: (1) dysthymic disorder (300.40) or adjustment disorder with depressed mood (309.00), labeled as minor depression, (2) major depression without melancholia or simple major depression (296.X2), and (3) major depression with melancholia (296.X3). The Hamilton Depression Rating Scale (HAM-D), 17-item version, was used in order to measure the severity of depression (Hamilton 1967). The SCID and HDRS were scored by the same author (i.e., AvG) \pm 8 days after hospital admission of patients.

Patients with other axis 1 diagnoses beside depression, such as substance use disorder $(1 / 2$ year previous to admission), organic mental disorder, and schizophrenia, were excluded from these studies. We have 
Table 1. Demographic Data of the 66 Subjects in This Study

\begin{tabular}{|c|c|c|c|c|c|c|c|c|}
\hline \multirow[b]{2}{*}{ Diagnostic Groups } & \multirow[b]{2}{*}{ Index } & \multirow{2}{*}{$\begin{array}{c}\text { Men/Women } \\
\text { Ratio }\end{array}$} & \multirow{2}{*}{$\begin{array}{l}\text { Age (years) } \\
\text { Mean } \pm \text { SD }\end{array}$} & \multirow{2}{*}{$\begin{array}{c}\text { HDRS }^{b} \\
\text { Mean } \pm S D\end{array}$} & \multirow[b]{2}{*}{$\mathrm{AD}$} & \multicolumn{3}{|c|}{ Drug State (yes/no) ${ }^{a}$} \\
\hline & & & & & & BZ1 & NL & BZ2 \\
\hline Healthy controls & $\mathrm{HC}$ & $11 / 13$ & $41.1 \pm 13.5$ & - & - & - & - & - \\
\hline Minor Depression & md & $4 / 8$ & $42.8 \pm 11.9$ & $16.2 \pm 3.6$ & $1 / 11$ & $4 / 8$ & $3 / 9$ & $3 / 9$ \\
\hline Simple major depression & $\mathrm{MD}-\mathrm{M}$ & $3 / 18$ & $48.7 \pm 14.3$ & $21.6 \pm 3.8$ & $3 / 18$ & $12 / 9$ & $3 / 18$ & $8 / 13$ \\
\hline Melancholia & $\mathrm{MD}+\mathrm{M}$ & $3 / 6$ & $58.7 \pm 14.0$ & $23.7 \pm 1.7$ & $4 / 5$ & $3 / 6$ & $1 / 8$ & $2 / 7$ \\
\hline ANOVA or $\chi^{2}$-test & & 3.9 & 3.6 & 14.6 & 2.7 & 1.2 & 0.2 & 0.3 \\
\hline$d f$ & & 3 & $3 / 58$ & $2 / 39$ & 2 & 2 & 2 & 2 \\
\hline$p$ & & 0.3 & 0.02 & $<10+$ & 0.3 & 0.5 & 0.9 & 0.9 \\
\hline
\end{tabular}

"Drug state: use' of antidepressants (AD), benzodiazepines (BZ1), or low-dosage antipsychotic agents (NL) the month prior to the 8-day washout period, or use of benzodiazepines $(B Z 2)$ during the study period.

"HDRS: Hamilton Depression Rating Scale, 17-item version.

excluded patients who were on lithium, monoamine oxidase inhibitors, (MAOI), antipsychotic dosages of neuroleptics and anticonvulsants or barbiturates, and patients who underwent electroconvulsive therapy (ECT) the year previous to hospital admission. The drug state of the patients before the eight-day washout period is listed in Table 1. Eight depressed patients have been treated with antidepressants, that is, maprotiline, clomipramine, amitriptyline; 19 subjects had been taking benzodiazepines, whereas seren patients were treated with a low dosage of typical neuroleptics, for example, equivalent of haloperidol $<0.5 \mathrm{mg} /$ day. These drugs were discontinued upon admission, and, subsequently, these subjects underwent a washout period of eight days. The authors administered a low dosage of benzodiazepines to 13 patients (equivalent of $\leqslant 25 \mathrm{mg}$ di-Kchlorazepate) in the case of severe agitation, anxiety, sleep disorders, or suicidal ideation. Inclusion criteria for normal controls and depressed subjects included normal blood tests such as liver function tests (e.g., SGPT, SGOT, and GGT), hematologic measures (e.g., hematocrit), electrolytes, and renal function tests (e.g., urea and creatinine). All patients had a normal radiograph of lungs and heart, electrocardiogram, and electroencephalogram. Subjects were on a low monoamine diet for three days prior to the blood samplings.

Normal volunteers were free of any medication during at least one month previous to blood sampling. All were free of medical and psychiatric illnesses. They were screened and excluded for present, past history, and family history of psychiatric disorder by means of a semistructured clinical interview based on the SCID. None had ever been taking psychotropic drugs or was a regular drinker. They had raw scores $<32$ on the Zung Depression and Anxiety Scales and $<9$ on the Beck Depression Inventory. All subjects were free of drugs known to interfere with endocrine or immune functions. All subjects were free of chronic illnesses known to affect the endocrine or immune status (e.g., diabetes, infections) and of acute infectious or allergic reactions for at least 2 weeks prior to the study.

\section{METHODS}

Fasting blood was sampled at 8:00 A.M., 8 days after hospital admission for the assay of serum L-TRP, the competing amino acids, valine, leucine, phenylalanine, isoleucine, and tyrosine, total serum protein, albumin, and the $\alpha_{2}$ globulin fraction. Amino acids were determined by means of a HPLC method as previously described by us (Maes et al. 1990c). The ratio of L-TRP to the sum of the five competing amino acids was computed. Total serum protein was assayed by means of the Kodak Ektachem Analyzer (Kodak, Vilvoorde, Belgium). The interassay and intraassay coefficients of variation (expressed as a percentage, CV\%) obtained in our laboratory were $2.16 \%$ and $0.83 \%$, respectively. Serum protein electrophoresis has been carried out by means of the Beckman Paragon SPE agarose system (Analis, Namur, Belgium) with densitometric quantitation of the protein fractions. The interassay and intraassay $\mathrm{CV}$ values for the percentages of albumin were $3.05 \%$ and $0.63 \%$, and for $\alpha_{2}$ globulin $7.05 \%$ and $3.64 \%$, respectively.

\section{STATISTICS}

Normality of distribution has been ascertained by means of the Kolmogorov-Smimov test. Relationships between variables have been ascertained by means of Pearson's product-moment or Spearman's rank-order correlation coefficients, multiple regression, or path analysis. The independence of classification systems has been checked with the analysis of contingence $\left(x^{2}\right.$ test). Mean group differences have been assessed with 
the analysis of variance (ANOVA) or covariance (ANCOVA). Multiple post-hoc comparisons between group means were checked with Fisher's least significant difference (LSD).

\section{RESULTS}

\section{Demographic Data}

Table 1 lists the demographic data of the 66 subjects in this study. There were no significant differences in men: women ratio between the four study groups. There were no significant differences in age among minor, simple major, and normal subjects. Patients with melancholia were somewhat older than the other groups (LSD at $p=$ $.05)$. The HAM-D ratings were significantly different among the three groups and increased from minor to simple major to melancholic depression. Correlation analyses pooled over the four diagnostic groups showed significant correlations between age and $\alpha_{2}$-globulin concentrations $(r=0.35, p=.005)$, percentage of $\alpha_{2}$-globulin $(\mathrm{r}=0.44, p=.0005)$, albumin concentrations $(\mathrm{r}=-0.35$, $p=.005)$, percentage of albumin $(r=-0.30, p=.01)$ and the L-TRP/competing amino acid ratio $(r=-0.31$, $p=.01)$. There were no significant correlations between age and total serum protein $(r=-0.18, p=.1)$ and serum L-TRP ( $\mathrm{r}=-0.09, p=.5$ ). There were no significant differences between men and women (results of ANOVAs, factorial design with diagnostic groups and gender as factors) in L-TRP ( $F=2.9, p=.09)$, L-TRP/ competing amino acid ratio $(\mathrm{F}=0.2, p=.7)$, total serum protein $(\mathrm{F}=0.2, p=.7)$, the percentage $(\mathrm{F}=3.1, p=.01)$ or concentration ( $\mathrm{F}=2.5, p=.1$ ) of $\alpha_{2}$-globulin, and percentage ( $\mathrm{F}=0.1, p=.7$ ) or concentration of albumin $(\mathrm{F}=0.04, p=.8)$. In any case, we have adjusted subsequent statistical tests for possible age and gender effects through multiple regression analyses with age and gender as additional explanatory variables.

There were no significant relationships between the
L-TRP or protein data and the drug state of the depressed patients, for instance, either use of benzodiazepines, antidepressants, or neuroleptics the month prior to the washout period or use of benzodiazepines during the study period. For example, the multiple regression of serum L-TRP concentrations on the four drug state variables was nonsignificant ( $\mathrm{F}=0.2$, $d f=4 / 37, p=.9$ ); none of the drug state variables was significant in this regression equation, for instance, use of antidepressants ( $\mathrm{F}=$ $0.4, p=.5)$, benzodiazepines ( $\mathrm{F}=0.2, p=.7$ ) or neuroleptics ( $\mathrm{F}=0.4, p=.5$ ) before the washout period, or use of benzodiazepines during the study span $(\mathrm{F}=0.00$, $p=9$. . The multiple regression of the L-TRP/competing amino acid ratio on the four drug state variables was nonsignificant $(F=2.0, d f=4 / 37, p=.1)$. Therefore, we have no evidence that the drug state of the patients has a major effect on our results.

\section{L-TRP, Proteins, and DSM-III-R Classification}

Table 2 lists the measurements of L-TRP, L-TRP/competing amino acids ratio, total serum protein, and protein fractions. Serum L-TRP was significantly lower in melancholic subjects compared to normal subjects and minor depressed subjects, whereas simple major depressed subjects occupied an intermediate position. Age $(\mathrm{F}=0.1, p=.7)$ and gender $(\mathrm{F}=2.4, p=.1)$ were not significant in the multiple regression analysis; diagnostic classification explained $20.7 \%$ of the variance in the L-TRP data. The L-TRP/competing amino acid ratio was significantly lower in depressed subjects than in normal controls, whereas melancholic subjects had the lowest ratio. Age $(\mathrm{F}=9.1, p=.004)$ and diagnostic classification $(\mathrm{F}=9.0, p=.004)$ explained $28.1 \%$ of the variance in the L-TRP/competing amino acid ratio; gender was not significant in this regression analysis. Total serum protein was significantly lower in major depressed patients than in normal controls and minor depressed subjects. The effects of diagnostic classification remained

Table 2. Measurements of Serum L-Tryptophan (L-TRP), L-TRP/Competing Amino Acids (CAA) Ratio, Total Serum Protein (TSP), Albumin and $\alpha_{2}$ Globulin Fraction in 66 Subjects $^{a}$

\begin{tabular}{|c|c|c|c|c|c|c|c|}
\hline \multirow[b]{2}{*}{ Index ${ }^{b}$} & \multirow{2}{*}{$\begin{array}{c}\text { L-TRP } \\
10^{-6} \text { mole } / \mathrm{L}\end{array}$} & \multirow{2}{*}{$\begin{array}{c}\text { L-TRP/CAA } \\
\times \mathbf{1 0 0}\end{array}$} & \multirow{2}{*}{$\begin{array}{l}\text { TSP } \\
\mathrm{g} / \mathrm{L} \\
\end{array}$} & \multicolumn{2}{|c|}{ Albumin } & \multicolumn{2}{|c|}{$\alpha_{2}$ globulin } \\
\hline & & & & $\%$ & $\mathrm{~g} / \mathrm{L}$ & $\%$ & $g / L$ \\
\hline $\mathrm{HC}$ & $76.4 \pm 11.2$ & $10.96 \pm 1.26$ & $73.6 \pm 3.4$ & $63.0 \pm 2.6$ & $46.4 \pm 2.7$ & $8.3 \pm 1.1$ & $6.1 \pm 0.8$ \\
\hline md & $74.7 \pm 17 . t$ & $9.66 \pm 1.90^{2}$ & $73.1 \pm 7.3$ & $65.4 \pm 3.3$ & $47.7 \pm 4.6$ & $9.5 \pm 1.1^{5}$ & $6.9 \pm 1.0^{6}$ \\
\hline $\mathrm{MD}-\mathrm{M}$ & $69.5 \pm 12.2$ & $9.74 \pm 1.80^{2}$ & $70.1 \pm 5.6^{3}$ & $64.6 \pm 3.1$ & $45.2 \pm 3.8$ & $9.5 \pm 1.4^{5}$ & $6.6 \pm 1.0$ \\
\hline $\mathrm{MD}+\mathrm{M}$ & $57.7 \pm 6.7^{1}$ & $8.50 \pm 1.02^{2}$ & $68.3 \pm 4.8^{3}$ & $62.1 \pm 3.2$ & $42.4 \pm 4.0^{4}$ & $10.2 \pm 1.7^{5}$ & $6.9 \pm 1.0^{6}$ \\
\hline ANOVAS $F$ & 5.4 & 5.4 & 3.3 & 3.1 & 4.1 & 5.9 & 3.1 \\
\hline df & $3 / 62$ & $3 / 62$ & $3 / 62$ & $3 / 62$ & $3 / 62$ & $3 / 62$ & $3 / 62$ \\
\hline$p$ & 0.003 & 0.003 & 0.02 & 0.03 & 0.01 & 0.002 & 0.03 \\
\hline
\end{tabular}

\footnotetext{
'All results are expressed as mean $( \pm S D)$.

1. $3,+$ Significantly different from HC or md; 2.7 "Significantly different from HC (all results of Fisher's LSD at $p=.05$ )

"HC/md/MD $\mathrm{M}$ : for explanation see Table 1.
} 
significant $(\mathrm{F}=5.0, p=.03)$ after considering the effects of age $(\mathrm{F}=2.4, p=.1)$ and gender $(\mathrm{F}=0.1, p=.8)$. Serum albumin was significantly lower in melancholic subjects than in normal controls and minor depressed subjects. After considering the effects of age $(\mathrm{F}=7.3, p=$ $.009)$ and gender $(F=0.00, p=.99)$, the effects of diagnostic classification ( $F=4.1, p=.04$ ) remained significant. Serum $\alpha_{2}$-globulin was significantly higher in depressed subjects than in normal controls (percentage as well as concentration). After considering the effects of age $(\mathrm{F}=13.6, p=.0008)$ and gender $(\mathrm{F}=2.7, p=.1)$, the effects of diagnostic classification $(F=8.3, p=.006)$ were still significant.

No significant Spearman's rank order correlation coefficients were found between serum L-TRP and anorexia $(r=-0.29, p=.06)$ and weight loss $(r=-0.20, p=$ .2). No significant Spearman's rank-order correlation coefficients were found between the L-TRP/competing amino acid ratio and either anorexia $(r=0.17, p=.3)$ or weight loss $(r=0.17, p=.3)$. There was a significant and positive relationship between anorexia and weight $\operatorname{loss}\left(\mathrm{r}=0.66, p<10^{4}\right)$. There were no significant relationships between anorexia or weight loss, on the one hand, and total serum protein, albumin, or $\alpha_{2}$-globulin (percentage or concentration), on the other.

\section{Relationships Between L-TRP and Proteins}

Table 3 shows the relationships between L-TRP or L-TRP / competing amino acid ratio and total serum protein or protein fractions in depressed subjects and normal controls, alone and together. In normal and depressed subjects and in all patients together, a highly significant and positive relationship was found between L-TRP and total serum protein. There were highly significant and positive relationships between serum L-TRP and serum albumin. In depressed subjects and in the study group as a whole-but not in normal volunteers-there were highly significant and inverse relationships between the $\alpha_{2}$-protein fraction (either percentage or concentration) and availability of L-TRP (either L-TRP or the ratio). There was a significant and negative correlation between serum albumin and the percentage of $\alpha_{2}$-globulin fraction $\left(\mathrm{r}=-0.53, p<10^{-4}\right)$. There was a highly significant correlation between total serum protein and albumin $(\mathrm{r}=$ $\left.0.83, p<10^{-4}\right)$, but not between total serum protein and $\alpha_{2}$-globulin fraction $(\mathrm{r}=0.10, p=.6)$.

\section{Results of Path Analysis}

In order to examine the complex interrelationships between L-TRP availability and total serum protein, albumin, $\alpha_{2}$-globulin, and other explanatory variables such as age, gender, and DSM-III-R classification, a causal model was tested by means of path analysis. In that model, L-TRP/competing amino acid ratio and L-TRP were considered the dependent variables (or the effects), whereas albumin and $\alpha_{2}$-globulin were considered to be direct causes (i.e., explanatory variables) of the variability in L-TRP availability. Finally, age, gender, and DSM-III-R classification were considered causes (explanatory variables) for each of the previous variables, that is L-TRP/ competing amino acid ratio, L-TRP, albumin, and $\alpha_{2}$-globulin. Gender, (i.e., $\operatorname{man}=1$, woman $=0$ ) and DSM-III-R classification (healthy controls $=0$, depressed subjects $=$ 1) were entered as dummy variables. Thus, this model allows to examine the causal relationships between protein fractions and L-TRP availability taking into account the effects of age, gender, and DSM-III-R classification.

Figure 1 shows the final path model, that is, after omitting nonsignificant paths, for instance, from age to serum albumin and L-TRP and from gender to serum albumin and L-TRP. We found that $55 \%$ of the variance in the L-TRP/competing amino acid ratio was explained by serum L-TRP, gender, $\alpha_{2}$-globulin fraction (percentage) and age $\left(\mathrm{F}=18.6, d f=4 / 61, p<10^{-4}\right)$. Thus, the significant correlation between L-TRP/competing amino acid ratio and $\alpha_{2}$-globulin fraction found in the total study group (see Table 3), holds after considering the effects of gender, age, and serum L-TRP levels. $30.8 \%$ of the variance in L-TRP was explained by the regression on serum albumin and DSM-III-R classification ( $\mathrm{F}=6.8, d f=4$ /

Table 3. Relationships among Serum L-Tryptophan (L-TRP), L-TRP/Competing Amino Acids (CAA) Ratio, Total Serum Protein (TSP), Albumin (Alb), and $\alpha_{2}$ Globulin Fractions

\begin{tabular}{llcc}
\hline Relationships & $\begin{array}{c}\text { Total Study } \\
\text { Group }(\boldsymbol{n}=\mathbf{6 6})\end{array}$ & $\begin{array}{c}\text { Depressed } \\
\text { Subjects }(\boldsymbol{n}=\mathbf{4 2})\end{array}$ & $\begin{array}{c}\text { Normal } \\
\text { Subjects }(\boldsymbol{n}=\mathbf{2 4})\end{array}$ \\
\hline TSP and L-TRP & $0.56\left(<10^{-4}\right)$ & $0.54(0.0004)$ & $0.49(0.01)$ \\
TSP and L-TRP/CAA & $0.25(0.04)$ & $0.12(0.5)$ & $0.31(0.1)$ \\
Alb and L-TRP & $0.46(0.0003)$ & $0.46(0.003)$ & $0.42(0.04)$ \\
Alb and L-TRP/CAA & $0.32(0.008)$ & $0.24(0.1)$ & $0.55(0.006)$ \\
$\alpha_{2} \% \%$ and L-TRP & $-0.33(0.007)$ & $-0.26(0.09)$ & $-0.17(0.6)$ \\
$\alpha_{2} \%$ and L-TRP/CAA & $-0.44(0.0004)$ & $-0.40(0.009)$ & $-0.08(0.7)$ \\
$\alpha_{2}$ and L-TRP & $-0.05(0.7)$ & $0.07(0.6)$ & $0.00(0.9)$ \\
$\alpha_{2}$ and L-TRP/CAA & $-0.34(0.005)$ & $-0.32(0.04)$ & $0.03(0.9)$ \\
\hline
\end{tabular}

Listed are Pearson's product moment correlation coefficients (with exact $p$-value). 


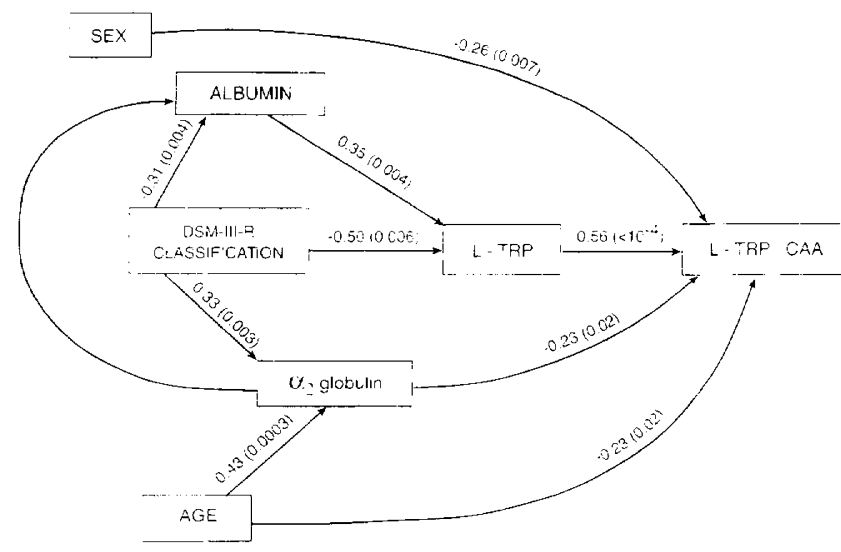

Figure 1. Results of path analysis. Shown is the final (overidentified) model, after exclusion of nonsignificant paths and nonsignificant variables. Listed are the path coefficients with exact $\mu$-value between brackets.

$61, p=.0003$ ). Thus, the significant correlation between L-TRP and albumin (see Table 3 ) holds after considering the effects of DSM-III-R classification, whereas age and gender did not affect this relationship. Of the variance in serum albumin, $37.1 \%$ was explained by $\alpha_{2}$-globulin fraction and DSM-III-R classification ( $F=18.6$, df $=3$ / $62, p=.00001)$. Of the variance in $\alpha_{2}$-globulin, $36.5 \%$ was explained by age and DSM-III-R grouping combined $(\mathrm{F}=18.2$, df $=2 / 63, p=.00001)$.

\section{DISCUSSION}

The major findings of this study are that: (1) the availability of L-TRP to the brain is significantly lower in depressed and, particularly in melancholic patients compared to normal controls; (2) the availability of L-TRP is significantly and positively related to total serum protein and serum albumin and inversely to serum $\alpha_{2}$-globulin fraction; and (3) lower L-TRP availability in depression may, in part, be explained by lower total serum protein or albumin concentrations or by an increase in the $\alpha_{2}$-globulin fraction. The results will now be discussed.

In accordance with several other reports, this study found lower L-TRP availability in depressed subjects and, in particular, in melancholic subjects compared with normal controls (Maes et al. 1990a; Cowen et al. 1989; Moller et al. 1986). A major finding of this study is the significant positive relationship between serum L-TRP and total serum protein or serum albumin in normal controls as well as in depressed subjects. The positive relationship between serum total L-TRP and albumin concentrations may be explained by the fact that $70 \%$ to $90 \%$ of L-TRP is bound to serum albumin (McMenamy and Oncley 1958). Thus, serum albumin concentrations appear to constitute a major determinant of serum L-TRP con- centrations in normal persons as well as in depressed subjects. Consequently, the decrease in serum albumin concentrations observed in depression may have caused lower serum total L-TRP concentrations because less L-TRP is bound to albumin. Moreover, as the path analysis showed that lower L-TRP in depression is, in part, determined (statistically) by lower serum albumin, it may be suggested that lower serum L-TRP in depression is secondary to lowered serum albumin in that illness. This may be of relevance for the influx of L-TRP into the brain, as the brain sees all the plasma L-TRP instead of only the free component (Pardridge 1979). Indeed, the BBB transport site of L-TRP strips off albumin as it passes through the brain capillaries (Pardridge 1979; Smith et al. 1990). As there is evidence that serum L-TRP availability is related to brain L-TRP contents and the metabolism of 5-HT in cerebro (Moir and Eccleston 1968; Maes and Meltzer 1995), lower serum albu$\mathrm{min}$ in depression may play a role in alterations in the central serotonergic metabolism in the brain of depressed subjects.

There was also a statistically highly significant positive correlation between total serum protein and serum L-TRP in normal subjects as well as in depressed patients. These findings are in accordance with one of our previous reports, showing significant positive withinsubject or time-relationships between both factors in 26 normal volunteers who had monthly blood samplings during one calendar year (Maes et al. 1995). Because the variance in total serum protein is greatly determined $(69 \%$ of the variance) by the variance in serum albumin, it may be suggested that the relationship between total serum protein and serum L-TRP is, in part, determined by that between albumin and L-TRP.

However, path analysis showed that part of the variance in serum L-TRP could be determined by the combined effects of lower serum albumin and DSM-III-R classification. These findings suggest that depression-related phenomena, other than the effects of albumin, may determine lower L-TRP availability in that illness. These phenomena may involve the following: (1) increased L-TRP catabolism through induction of liver pyrrolase by increased glucocorticoid activity in major depression (Maes et al. 1990b; Morgan and Badawy 1989) or (2) increased catabolism of L-TRP through induction of IDO by increased interferon- $\gamma$ secretion in major depression (Maes et al. 1994b).

A second major finding of this study is the significant inverse relationship between the L-TRP/competing amino acid ratio and serum $\alpha_{2}$-globulin fraction (either percentage or concentration) in depressed patients, but not in normal controls. Path analysis showed that an important part of the variance in the L-TRP/competing amino acid ratio was explained by the combined effects of serum $\alpha_{2}$-globulin fraction and serum L-TRP, which, in turn, was partly determined by serum albu- 
min. Thus, it appears that the relationship between the $\alpha_{2}$-globulin fraction and the L-TRP/competing amino acid ratio reflects changes in the relative distribution of total L-TRP versus the competing amino acids. These findings corroborate one of our previous studies, reporting a significant inverse relationship in depressed patients between plasma haptoglobin, which migrates in the $\alpha_{2}$-globulin zone (Putnam 1984a,b) and L-TRP availability (Maes et al. 1993).

As summarized previously, there is now some evidence that major depression is accompanied by an acute phase response. The decrease in total serum protein and serum albumin and the increase in $\alpha_{2}$-globulin in depression or melancholia further underscore this theory. Indeed, albumin is one of the negative acute phase proteins, which has been shown to be reduced in depression (Swartz 1990; Maes et al. 1991; Song et al. 1994) and in the olfactory bulbectomized rat model of depression (Song and Leonard 1994), whereas positive acute phase proteins, such as haptoglobin and ceruloplasmin, are known to migrate in the $\alpha_{2}$ zone (Ritzmann and Daniels 1976; Putnam 1984a,b). Thus, the present study shows that the lower availability of total L-TRP to the brain in depression is related to indicants of the acute phase response in that illness. These findings corroborate our previous report that there is a highly significant positive correlation in depression between L-TRP availability and production of IL-6, the key mediator of the acute phase response in human (Castell et al. 1989; Prowse and Baumann 1989; Heinrich et al. 1990; Maver et al. 1991). Therefore, it is a reasonable theory that lower L-TRP availability in depression reflects, in part, the acute phase response in that illness.

It could be argued that malnutrition accompanying the anorexia or weight loss of depression may be related to reduced total serum protein, serum albumin, and L-TRP availability. Howerer, in the present study, no significant relationships were found between L-TRP availability to the brain, serum L-TRP, or the L-TRP/competing amino acid ratio, and anorexia or weight loss. Moreover, this study showed that lower serum L-TRP as well as lower serum albumin were significantly and negatively related to increased $\alpha_{2}$-globulin, another electrophoretically separated serum protein fraction, which indicates the presence of an acute phase response in depression. In this respect, Fleck (1989) has suggested that reductions in negative acute phase proteins, such as albumin and, consequently, total serum protein, may not be assumed to reflect a primary malnutrition when there is evidence for an acute phase response. Moreover, no nutritional disorders indicating protein loss due to malnutrition could be found in depression (Maes et al. 1991). Finally, the role of dietary effects on the control of L-TRP availability to the brain is rather small (review: Curzon 1990). Thus, fasting for up to 5 days had little effect on plasma L-TRP concentrations in the rat (Curzon 1990).
It was found that plasma competing amino acid concentrations were unaffected by breakfast in freely feeding adults (Scriver et al. 1985; Milson et al. 1979). The L-TRP/ competing amino acid ratio altered only moderately, if at all, in subjects given meals of considerably different composition (Ashley et al. 1982, 1985). Physiologically relevant differences in protein intake do not induce alterations in the L-TRP/competing amino acid ratio (Fernstrom et al. 1987). Thus, there is no evidence that lower L-TRP availability to the brain is determined by malnutrition due to the anorexia or weight loss occurring in depression.

In conclusion, this study showed that the reduced availability of L-TRP to the brain is related to lower albumin and, consequently, total serum protein concentrations and to $\alpha_{2}-$ globulin fraction. These findings suggest that lowered L-TRP availability to the brain may be secondary to the acute phase response in depression.

\section{ACKNOWLEDGMENTS}

The research reported was supported, in part, by the National Funds Scientific Research (NFWO) and the IUAP Program, Belgium. The secretarial assistance of Mrs. M. Maes is greatly appreciated

\section{REFERENCES}

American Psychiatric Association (1987): Diagnostic and Statistical Manual of Mental Disorders. Washington, DC, American Psychiatric Association

Arnold FJ, Meyerson LR (1990): Olfactory bulbectomy alters alpha-1 acid glycoprotein levels in rat plasma. Br Res Bull 25:259-262

Ashley DVM, Barclay DV, Chauffard FE et al. (1982): Plasma amino acid responses in humans to evening meals of differing nutritional composition. Am J Clin Nutr 36: $143-153$

Ashley DVM, Liardon R, Leathwood PD (1985): Breakfast meal composition influences plasma tryptophan to large neutral amino acid ratios of healthy lean young men. J Neural Transm 63:271-283

Blackburn GL, Moldawer LL, Usui S, Bothe AJr, O'Keefe SID, Bistrian BR (1979): Branched chain amino acid administration and metabolism during starvation, injury, and infection. Surgery 86:307-314

Brown RR, Lee CM, Kohler PC, Hank JA, Storer BE, Sondel PM (1989): Altered tryptophan and neopterin metabolism in cancer patients treated with recombinant interleukin-2. Cancer Res 49:4941-4944

Castell JV, Gomez-Lechon MJ, David M, Andus T, Geiger T, Trullenque R, Fabra R, Heinrich PC (1989): Interleukin-6 is the major regulator of acute phase protein synthesis in adult human hepatocytes. FEBS Lett 242:237-239

Cowen PJ, Parry-Billings M, Newsholme EA (1989): Decreased plasma tryptophan levels in major depression. I Affect Disord 16:27-31 
Curzon G (1990): Availability of amino acids to the brain and implication for transmitter amine function. In Richardson MA (ed), Amino Acids in Psychiatric Disease. Washington DC, American Psychiatric Press, pp 33-48

Curzon G, Knott PJ (1975): Rapid effects of environmental disturbance on rat plasma unesterified fatty acid and tryptophan concentrations and their prevention by antilipolytic drugs. Br J Pharmacol 54:389-396

Curzon G, Sarna GS (1984): Trvptophan transport to the brain: Newer findings and older ones reconsidered. In Schlossberger HG, Kochen W, Linzen B, Steinhart H (eds), Progress in Tryptophan and Serotonin Research. BerlinNew York, Walter De Gruyter, pp 145-157

Delgado P'L, Charney DS, Price LH, Landis H, Heninger GR (1990): Neuroendocrine and behavioral effects of dietary tryptophan restriction in healthy subjects. Life Sci 45 : 2323-2332

DeMver MK, Shea PA, Hendric HG, Yoshimura N. (1981): Plasma tryptophan and five other amino acids in depressed and normal subjects. Arch Gen Psychiatry 38 : $642-6+6$

Fernstrom JD (1984): Tryptophan availability and serotonin synthesis in rat brain: Effects of experimental diabetes. In Schlossberger HG, Kochen W, Linzen B, Steinhart H (eds), Progress in Tryptophan and Serotonin Research. Berlin-New York, Walter de Gruyter, pp 161-172

Fernstrom JD, Fernstrom MH, Grubb PE (1987): Twenty-four hour variations in rat blood and brain levels of the aromatic and branched-chain amino acids: Chronic effects of dietary protein content. Metabol 36:643-650

Fleck A (1989): Clinical and nutritional aspects of changes in acute-phase proteins during inflammation. Proc Nutr Soc $48: 347-354$

Fuchs D, Moller AA, Reibnegger G, Stockle E, Werner ER, Wachter H (1990): Decreased serum tryptophan in patients with HIV-1 infection correlates with increased serum neopterin and with neurologic/psychiatric symptoms. J AlDS 3:873-876

Fuchs D, Moller AA, Reibnegger G, Werner ER, Werner-Felmayer G, Dierich MP, Wachter H (1991): Increased endogenous interferon-gamma and neopterin correlate with increased degradation of tryptophan in human immunodeficiency virus type 1 infection. Immunol Lett 28:207211

Hamilton M (1967): Development of a rating scale for primary depressive illness. Br J Soc Clin Psychol 6:278-296

Hasselgren PO, Pedersen P, Sax, HC, Warner BW, Fischer JE (1988): Current concepts of protein turnover and amino acid transport in liver and skeletal muscle during sepsis. Arch Surgery 123:992-499

Heinrich PC, Castell JV, Andus T (1990): Interleukin-6 and the acute phase response. Biochem ] 265:621-636

Heninger GR, Delgado PL, Charney DS, Price LH, Aghajanian GK (1992): Tryptophan-deficient diet and amino acid drink deplete plasma tryptophan and induce a relapse of depression in susceptible patients. I Chem Neuroanatomy $5: 347-348$

Hirano T ( $|99|)$ : Interleukin-6. In Thomson AW (ed), The Cytokine Handbook. London, Academic Press, pp 169-190

Joyce PR, Hawes CR, Mulder RT, Sellman ID, Wilson DA,
Boswell DR (1992): Elevated levels of acute phase plasma proteins in major depression. Biol Psychiatry 32:1035-1041

Mackiewicz A, Ganapathi MK, Schultz D, Samols D, Reese J, Kuchner l (1988): Regulation of rabbit acute phase protein biosynthesis by monokines. Biochem J 258:851-857

McMenamy RH, Oncley JL (1958): The specific binding of L-tryptophan to serum albumin. J Biol Chem 233:14361440

Maes M, Jacobs M-P, Suy E, Minner B, Leclercq C, Christiaens F, Raus J (1990a): Suppressant effects of dexamethasone on the availability of plasma L-tryptophan and tyrosine in healthy controls and in depressed patients. Acta Psychiatr Scand 81:19-23

Maes M, Jacobs M-P, Suy E, Vandewoude M, Minner B, Raus $J(1990 \mathrm{~b})$ : Effects of dexamethasone on the availability of L-tryptophan and on the insulin and FFA concentrations in unipolar depressed patients. Biol Psychiatry 27:854-862

Maes M, Schotte C, Scharpé S, Martin M, Blockx P (1990c): The effects of glucocorticoids on the availability of L-tryptophan and tyrosine in the plasma of depressed patients. J Affect Disord 18:121-127

Maes M, Vandewoude M, Scharpé S, DeClerck L, Stevens W, Lepoutre L, Schotte C (1991): Anthropometric and biochemical assessment of the nutritional state in depression: Evidence for lower visceral protein plasma levels in depression. J Affect Disord 23:25-33

Maes M, Scharpé S, Van Grootel L, Uyttenbroeck W, Cooreman W, Cosyns P, Suy E (1992a): Higher $\alpha_{3}$-antitrypsin, haptoglobin, ceruloplasmin and lower retinol binding protein plasma levels during depression: Further evidence for the existence of an inflammatory response during that illness. J Affect Disord 24:183-192

Maes M, Scharpé S, Bosmans E, Vandewoude M, Suy E, Uyttenbroek W, Cocreman W, Vandervorst C, Raus J (1992b): Disturbances in acute phase plasma proteins during melancholia: Additional evidence for the presence of an inflammatory process during that illness. Progr Psychopharmacol Biol Psychiatry 16:501-515

Maes M, Meltzer HY, Scharpé S, Bosmans E, Suy E, Minner B, De Meester I, Calabrese ], Vandervorst C, Raus J, Cosyns P' (1993): Relationships between lower plasma L-tryptophan levels and immune variables in depression. Psychiatr Res 49:11-27

Maes M, De Langhe H, Sharpé S, Meltzer HY, Cosyns P, Suy E, Bosmans E (1994a): Haptoglobin phenotypes and gene frequencies in unipolar major depression. Am J Psychiatry $151: 112-116$

Maes M, Scharpé S, Meltzer HY, Okayli G, Bosmans E, D’Hondt $P$, Vanden Bossche B, Cosyns P (1994b): Increased neopterin and interferon $\gamma$ secretion and lower availability of L-tryptophan in major depression: Further evidence for activation of cell-mediated immunity. Psychiatry Res 54: $143-160$

Maes M, Meltzer HYM (1995): The serotonin hypothesis of major depression. In Bloom F, Kupher D (eds), Psychopharmacology: The Fourth Generation of Progress. New York, Raven Press, pp 933-941

Maes M, Scharpé S, Verkerk R, D'Hondt P, Peeters D, Cosyns P, Thompson I', De Mever F, Wauters A, Neels H (1995): Components of biological variation, including seasonality in plasma L-tryptophan and competing amino-acids 
in man: Relationships to serum total protein, climatic variables, and violent suicide occurrence. Arch Gen Psychiatry 52:937-946

Mayer P, Geissler K, Valent P, Ceska M, Bettelheim P, Liehl E (1991): Recombinant human interleukin-6 is a potent inducer of the acute phase response and elevates the blood platelets in nonhuman primates. Exp Hematol 19:688-696

Milson JP, Morgan MY, Sherlock S (1979): Factors affecting plasma amino acid concentrations in control subjects. Metabol 28:313-319

Moir ATB, Eccleston D (1968): The effect of precursor loading in the cercbral metabolism of 5-hydroxyindoles. J Neurochem 15:1093-1108

Moldawer LL, Georgieff M, Lundholm K (1987): Interleukin-1, tumor necrosis factor-alpha (cachectin) and the pathogenesis of cancer cachexia. Clin Physiol 7:263-274

Moller SE, de Beurs P, Timmerman L, Tan BK, Leynse-Ybema H], Cohen Stuart MH, Hoptner Petersen HE (1986): Plasma tryptophan and tyrosine ratios to competing amino acids in relation to antidepressant response to citalopram and maprotiline: A preliminary study. Psychopharmacology 88:96-100

Morgan CJ, Badawy AA-B (1989): Effects of a suppression test dose of dexamethasone on tryptophan metabolism and disposition in the rat. Biol Psychiatry 25:360-362

Moroni F, Russi P, Gallo-Mezo MA, Moneti G, Pellicciari R (1991): Modulation of quinolinic and kynurenic acid content in the rat brain: effects of endotoxins and nicotinylalanine. I Neurochem 57:1630-1635

Pardridge WM (1979): Tryptophan transport through the blood-brain barrier: in vivo measurement of free and albumin-bound amino acid. Life Sci 25:1519-1528

Prowse KR, Baumann H (1989): Interleukin-1 and interleukin-6 stimulate acute phase protein production in primary mouse hepatocytes. I Leukocy te Biol 45:55-61

Putnam FW (1984a): Progress in plasma proteins. In The I'lasma Proteins: Structure, Function, and Genetic Control, 2nd ed. Orlando, Academic Press, pp 2-44

Putnam FW (1984b): Alpha, beta, gamma, omega-The structure of plasma proteins. In The Plasma Proteins: Structure, Function, and Genetic Control, 2nd ed. Orlando, Academic Press, pp +6-166

Rao ML (1987): Bioavailability of amino acids and amino acid precursors for neurotransmitter action: The role of hormones. In Huether G (eds), Amino Acid Availability and Brain Function in Health and Disease. Berlin, Springer Verlag, pp 29-38
Ritzmann SE, Daniels JC (1976): Serum protein electrophoresis and total serum proteins. In Serum Protein Abnormalities: Diagnostic and Clinical Aspects. Boston, Little, Brown and Company, pp 3-25

Scriver CR, Gregory DM, Sovetts D et al. (1985): Normal plasmafree amino acid values in adults: The influence of some common physiological variables. Metabol 34:868-873

Sluzewska A, Rybakowski JK, Laciak M, Mackiewicz A, Sobieska M, Wiktorowicz K (1995a): Interleukin-6 serum levels in depressed patients before and after treatment with fluoxetine. Ann NY Acad Sci 762:474-476

Sluzewska A, Rybakowski J, Sobieska M, Wiktorowicz K (1995b): Concentration and microheterogeneity glycophorms of $\alpha_{1}$-acid glycoprotein in major depressive disorder. J Affective Disord in press

Smith QR, Fukui S, Robinson P, Rapaport SI (1990): Influence of cerebral blood flow on tryptophan uptake into brain. In Lubec G, Rosenthal GA (eds), Amino Acids: Chemistry, Biology, and Medicine. Leiden, Escom, pp 364-369

Song C, Dinan T, Leonard BE (1994): Changes in immunoglobulin, complement and acute phase protein levels in the depressed patients and normal controls. J Affective Disord 30:283-288

Song C, Leonard BE (1994): An acute phase protein response in the olfactory bulbectomised rat: Effect of sertraline treatment. Med Sci Res 22:313-314

Spitzer RL, Williams JBW, Gibbon M, First MB (1990): Structured Clinical Interview According to DSM-III-R. New York, American Press

Swartz CM (1990): Albumin decrement in depression and cholesterol decrement in mania. J Affective Disord 19:173-176

Takikawa O, Yoshida R, Yasui H, Hayaishi O (1984): The relationship between plasma kynurenine and indoleamine 2,3-dioxygenase activity in the extrahepatic tissues. In Schlossberger HG, Kochen W, Linzen B, Steinhart H (eds), Progress in Tryptophan and Serotonin Research. Berlin, Walter de Gruyter and Co, pp 517-520

Wolvekamp MCJ, Marquet RL (1990): Interleukin-6: Historical background, genetics, and biological significance. Immunol Lett 24:1-10

Young SN, Smith SE, Pihl R, Ervin FR (1985): Tryptophan depletion causes a rapid lowering of mood in normal males. Psychopharmacology 87:173-177

Yuwiler A, Oldendorf WH, Geller E et al. (1977): The effect of albumin binding and amino acid composition on tryptophan uptake into the brain. J Neurochem 28:1015-1023 